\title{
Repercussions of Chinese land deals in South America: vectors of mobilization and domestic institutions
}

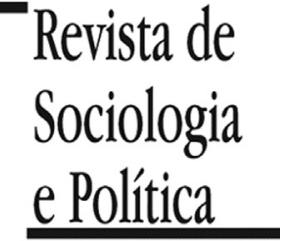

DOI 10.1590/1678-987320287407

\author{
Niels Søndergaard' \\ Insper Agro Global, Insper, São Paulo, SP, Brazil.
}

\begin{abstract}
Introduction: The article analyses domestic reactions to Chinese land deals in Brazil, Argentina and Bolivia, and how such attempts have affected these countries' regulatory framework for foreign land acquisitions. Materials and Methods: Mobilizations against these deals are examined with focus on their internal composition of social forces, and the framings which they produce in order to press for regulatory restrictions. Results: The emergence of protest in Argentina and Brazil, relative to the lack of opposition in Bolivia, is explained through a most similar case design, emphasizing differences in the rural socio-economic structure and composition of capital within the agricultural sector as central explanatory factors, accounting for the variation of the outcome in the cases examined. Discussion: With point of departure in the debate about global land investment, the article contributes to understanding how foreign investment is accommodated within different modes of commodity dependent development.
\end{abstract}

KEYWORDS: Land governance; South America; Land conflict; China; Agribusiness.

Received in April 14, 2019. Approved in February 27, 2020. Accepted in May 26, 2020.

\section{Introduction}

$\mathrm{I}$ n recent years, attempted Chinese land deals in different South American countries have drawn much public attention, and varying domestic repercussions. This study examines domestic reactions to planned Chinese land acquisitions within the soy sector in Brazil, Argentina, and Bolivia. With focus on attempted large-scale Chinese deals in West Bahia in Brazil, Rio Negro in Argentina, and Santa Cruz in Bolivia, the article analyses the processes whereby different domestic actors in these countries responded to such agreements. With point of departure in literature on land investments and in writings on contentious politics, the study scrutinizes how the prospects of Chinese land deals mobilize different domestic stakeholders, which through negative public framing of the issue generate pressures for more restrictive regulation. This general process largely applies to the Brazilian and Argentinean cases, while there is an apparent absence of major protest in Bolivia. A most similar case design (George \& Bennett 2005) is applied to account for the significant opposition to Chinese land purchases in Brazil and Argentina, considering the backdrop of the absence of protest in Bolivia. The diverging domestic reactions to these deals are explained through analysis of the rural socioeconomic structure and mode of production, as well as the differences in the international economic insertion of each of these countries. In the following sections this article proceeds with; 2) a review on the literature on land grabs and contentious politics within the field of agriculture, 3 ) a section presenting the article's methodological considerations and case selection procedure, 4) an analysis of each of the three country cases selected, and 5) the conclusions and final discussion. 


\section{Perspectives on land grabbing and resistance}

Different inquiries within the field of contentious politics have led to contributions that emphasize the connectedness between the particular spatial and temporal locus of land conflicts, and their embeddedness within broader historical and geographical social processes. Contextual factors may thus define the latent potential for land conflicts, while localized conditions trigger such events. Land change contestations may thus materialize as intersections of social dynamics rooted at the regional, national, and transnational level (Aldrich et al., 2012), while simultaneously being transgressive of such compartmentalizations. While the politics around land grabbing involve a variety of actors on different social levels, a body of scholarly work tends to emphasize contestations 'from below', and not least how the complex array of socioeconomic drivers of land conflict can lead to diverse social responses, and very heterogeneous counter-reactions (Hall et al., 2015). This highlights the need to examine the political spaces where expressions of contestation are made, with a particular eye to the channels of admittance to such spheres, which defines the degree of access which different societal actors enjoy (Wells-Dang 2010, p.94). These considerations lead to the formulation of research question 1:

- How have Chinese land deals intersected with the existing socioeconomic land tenure structure and latent conflict potential?

Understanding the domestic repercussions of Chinese attempts at largescale land acquisitions in South America warrants identification of the central stakeholders in this process, and how these are positioned within a terrain of contestation vis-à-via propagation of this development. Rocheleau (2015) illustrates how both proponents and opposition to land deals can assume a networked structure, through coalitions spanning across different societal spheres. The potentially wide-ranging socio-environmental implications of land investments may thus spur the joint organization of actors with otherwise diverging motivations (Temper 2018, p.209). Opposition can thereby be highly heterogeneous, and even include domestic agribusiness interests (Mamonova 2015).

Another group of studies tends to highlight the particular modes of resistance adopted by actors contrary to land deals. These contributions emphasize how opposition has gained diverse expressions, spanning from peaceful manifestations of discontent to direct violent conflict (Anseeuw \& Taylor 2014), and official channels of protest, to more unorganized and indirect means of rejection (Moreda 2015). Disparate power relations between the state, agro-capital, and rural population do not necessarily compress the scope for contestation, but rather lead to distinct modes of opposition (Schneider 2011). Kerkvliet (2009) thus makes a three-pronged conceptualization of peasant political expression, comprising of 1) official politics, engaging with established authorities and organizations, 2) advocacy politics, referring to organized opposition in relation to authorities, and 3) everyday politics, involving relatively unorganized expressions of protest through quotidian and often subtle acts of resistance (Kerkvliet 2009, p.231-232). Research question 2 has thus been formulated as the following:

- Which domestic constellations of opposition have the Chinese land deals engendered, and what means of protest have been applied?

Accounts of foreign land grabbing constitute a potentially very powerful storyline of dispossession. Land disputes are often marked by conflicting narratives, which, depending on their successful proliferation, define the practical viability of advancing such projects (Smalley \& Corbera 2012). The process of framing land deals can thereby both define the extent of public awareness/alarm 
(Borras \& Franco 2010, p.7), and may also place this phenomenon as the central object of the coalescence of social and environmental preoccupations (Temper 2018, p.200). Yet, other contributions have also highlighted how narrative accounts of land investments often also become open for selective and opportunistic appropriation by elites (Baird 2014; Scoones et al., 2013, p.476). Research question 3 has thus aims to explore which dominant representations of the attempted Chinese land deals have become evident within the public debates:

- Which public framings have prevailed in the reactions to Chinese land deals, and how have different social groups engaged in their construction?

Acts of resistance to the global land rush may spill over into changes within institutions for land governance. Cotula (2013) applies the Polaniyan notion of a double movement to conceptualize incipient signs of re-imposition of social concerns within otherwise strongly market-oriented regulatory frameworks in trends within international investment law. A similar movement on the domestic level, from popular opposition, which eventually results in regulatory restrictions towards foreign land investments, has also been detected by McAllister (2015, p.823). The state's structurating agency hereby becomes central in mediating often contrary social pressures for regulatory changes regarding large-scale land deals (Oliveira 2016). Research question 4 thus seeks to assess the potential legislative responses to the attempted Chinese land deals:

- To which extent have reactions to Chinese land deals spurred regulatory action within the national institutional framework for land governance?

The reviewed literature thereby suggests that the process of domestic contestation of Chinese land deals may be ordered in a causal sequence, in which 1) the rural socioeconomic context defines the latent potential for 2) organized opposition to Chinese land grabs, producing 3) negative public framing of these deals, and eventually results in 4) restrictive legislation to foreign land acquisitions. This would lead to the assumption that the multifaceted socioeconomic and environmental implications related to foreign land investment wield the potential to spur cross-sectorial mobilizations in heterogeneous constellations of social, corporate, and public actors. The manner in which such actors subsequently contribute to the public framing of this issue is thereby viewed within the present analysis as the product of intentional action, with the goal of obtaining a specific legislative result.

\section{An approach to contemporary land deals}

Since the global food crisis of 2007-2008, demand for farmland has undergone dramatic periodic accelerations beyond anything previously witnessed. While for comparison, the total area of global farmland expanded less than 4 million hectares annually before 2008, land deals involving 56 million hectares were proclaimed in 2009 (World Bank 2011). These large-scale farmland acquisitions by states and private investors first became known as a "land grabs", in 2008 (GRAIN 2008), - a term widely used since then. Not least the appropriations of large tracts of land in developing countries by developed states, from 2006 and onwards, spurred much international attention and preoccupation (Food scarce sparks Third World land rush 2009).

Although much scholarly work has examined global land deals in the aftermath of the food crisis, empirical assessments of the extent of this phenomenon have been relatively difficult (White et al., 2012, p.620). Focus has gradually moved from initial quantitative estimates of land deals as measured in hectares, towards conceptualizations of the modalities and diverse expressions of this de- 
velopment (Sauer \& Borras 2016). Debate about how to outline contemporary land investments have therefore revolved around specific definitions, measurement, their drivers and central actors, and consequent political reactions (Edelman, Oya \& Borras 2013, p.1518). With the potential shortcomings associated with purely quantitative analyses of land grabbing in mind (Scoones et al., 2013; Edelman 2013), the data initially presented is meant to provide an 'indicative' overview (Edelman 2013, p.497) of the phenomenon of Chinese land investments in Latin America, upon which a more qualitative analysis is undertaken. Numbers from GRAIN are included in the study, as this database, along with Land Matrix, constitute some of the most widely applied informational sources available. For the present purpose, GRAIN holds an advantage of providing a static "snapshot" of deals concluded by 2016, in contrast to the more dynamic database of Land Matrix. The GRAIN database registers foreign investments in farmland that have been concluded since 2006, and which comprise of areas above 500 hectares (GRAIN 2016).

The bulk of the analysis employs qualitative evidence from different sources. Whenever possible, a critical review of existing literature undertaking an in depth analysis of the political processes examined has been conducted. Yet, due to a relative scarcity of information on certain aspects of the cases examined, news reports and email questionnaires have also been made use of. The questionnaires have been sent to specialists in land tenure issues and/or NGO representatives working within the field in the countries analyzed. They have been structured according to an open-ended format, allowing each respondent to elaborate on the issues of interest in her/his own words. Legal provisions have also been scrutinized and their implications synthesized in certain parts of the article.

The global land rush has been strongly felt in Latin America, where largescale land deals have spiked in the wake of the food crisis (Flexor \& Leite 2017, p.394; Sauer 2010, p.78; Brent et al., 2017). Estimates conducted by the World Bank indicate that Latin America, together with Sub-Saharan Africa, will account for two-thirds of new agricultural land brought into production towards 2030 (World Bank 2011, p.xxviii). Land investments in Latin America has prompted discussions of national sovereignty, as its contemporary financialized character constitutes a more intensified version of historical processes of foreign land acquisitions, which today are expressed by surging land prices and rural conflict (Castro \& Igreja 2017, p.175).

Interest in Latin American agriculture on behalf of both public and private Chinese actors has also become evident in recent years. Apart from land acquisition, attention has also been focused on participation in the regional agro-industrial complex, which hitherto has been dominated by Western multinationals (Myers 2013). Chinese attempts to purchase or lease large tracts of farmland in Latin America have often been met by negative public reactions, in spite of their relatively limited extension (Myers 2013; Myers \& Jie 2015). As is illustrated in Table 1, confirmed land deals with Chinese investors in Bolivia, Brazil, and Argentina nonetheless constitute a relatively modest share of total foreign land grabs in these countries.

Although larger land deals, comparable to those of Western investors, have been attempted, they have largely been unsuccessful, particularly in Brazil and Argentina. As is illustrated in Table 2, different Chinese mega-deals proposed in Brazil and Argentina have not materialized, while the single major deal which was planned in Bolivia, has been confirmed.

The Bolivian deal refers to the sale of 12.488 hectares for soybean, sorghum, and maize cultivation in the province of Santa Cruz, to the Shanghai Pengxin Group in 2005. While significant deals implying the Chinese acquisi- 
Table 1 - Proportion of Chinese land acquisitions in Bolivia, Brazil and Argentina from 2005-2016

\begin{tabular}{lccc}
\hline Country & $\begin{array}{c}\text { Confirmed Chinese land } \\
\text { deals in hectares }\end{array}$ & $\begin{array}{c}\text { Total area of confirmed foreign } \\
\text { land deals in hectares }\end{array}$ & $\begin{array}{c}\text { Chinese land deals as percent- } \\
\text { age of total foreign land deals }\end{array}$ \\
\hline Bolivia & 12.488 & 67.845 & $18.4 \%$ \\
Brazil & 213.600 & 2.721 .102 & $7.8 \%$ \\
Argentina & 22.000 & 513.116 & $4.2 \%$ \\
\hline
\end{tabular}

Source: calculations based on GRAIN 2016.

Table 2 - List of concluded and unconcluded Chinese land deals in Bolivia, Brazil, and Argentina from 2005-2016

\begin{tabular}{llcc}
\hline Country & Purchaser & Area in hectares & Status of Agreement \\
\hline Argentina & Beidahuang & 320.000 & Failed \\
Argentina & China Grains and Oils Group Corporation & 22.000 & Concluded \\
Bolivia & Pengxin Group & 12.488 & Concluded \\
Brazil & Universo Verde Agronegócios Ltd (Chongqing) & 68.600 & Concluded \\
Brazil & COFCO Agri Ltd & 145.000 & Concluded \\
Brazil & Chongqing & 200.000 & Failed $^{\text {I }}$ \\
\hline
\end{tabular}

Source: GRAIN 2016.

${ }^{\text {I }}$ While the 200.000 ha. deal by Chongquing in Bahia did not materialize, the company did manage to aquire some of the areas of interest to it. The succesfull 68.8000 ha. deal made by this company through its subsidiary, Universo Verde Agronegócios, and the stalled 200.000 ha. deal are therefore not completely seperable, but have here been distinguished for the purpose of clarity.

tions of 145.000 and 68.600 hectares in Brazil, and 22.000 in Argentina have been concluded, the stalled attempts at obtaining 200.000 hectares in Brazil, and 320.000 hectares in Argentina nonetheless draw attention. The obstacles which Chinese land acquisitions have faced in Brazil and Argentina, compared to Bolivia, therefore make it relevant to examine how reactions to these attempted purchases unfolded within each country, and which factors might explain this variation.

As Chinese land purchases faced strong domestic opposition and significant regulatory changes in Brazil and Argentina, while no significant protest materialized in Bolivia, these differences are approached through a most similar case design (George \& Bennett 2005). This case design aims at identifying crucial differences in cases which otherwise share many similarities, by assessing the importance of essential variables which may account for the difference in outcomes. For the present purpose, this implies that because the chosen cases share many similarities in factors that potentially might define reactions to Chinese land deals, explanations for their different outcomes are sought in a more restricted spectrum of socio-economic circumstances on which they vary. Brazil, Argentina, and Bolivia are all marked by extensive land investments in recent years. Apart from Venezuela, Suriname and Jamaica, these are also the only states in Latin America and the Caribbean where the American Enterprise Institute identifies Chinese agricultural investments (AEI 2018). All three countries have been marked by a stable relationship to China, and rapidly increasing FDI inflows and increasing commercial interconnectedness with, this Asian country throughout the 2000s, thus constituting a central commonality across the cases. Brazil, Argentina, and Bolivia are also all characterized by a very extensive scale of agricultural cultivation practices which has permitted intensive production of grains and oilseeds in the Pampa, Chaco, and Cerrado regions. Cases of land purchases for soy production are chosen, as this mode of agro-industrial development often engenders particular socio-environmental pressures, and 
consequent opposition. Finally, notwithstanding democratic challenges in all of these countries, they are still characterized by an institutional environment which in the period examined has been largely permissive of organized protest, thus differing from the case of Venezuela ${ }^{1}$.

\section{An analysis of each of the three country cases selected}

${ }^{1}$ According to GRAIN (2016)

Latin American countries where large-scale Chinese land deals or attempted land deals have materialized are Argentina, Bolivia, Brazil, Jamaica and Venezuela.
The abovementioned circumstances make it possible to hold certain fundamental contextual factors constant across all cases, while focusing on variation in the rural socioeconomic landscape and the structure of domestic agribusiness capital in order to explain differences in the repercussions which Chinese investments have had within each particular case. In order to assess the causal significance of the potentially crucial factors in each case examined, evidence has been sought from different informational sources, such as existing studies within the field, news articles, key interviewees, and statistical databases. Interviewees from either civil society organizations or academic experts within the field were selected and contacted by email on basis of their specific knowledge in relation to the cases analyzed.

\section{IV.1 The West Bahia land deal and Brazilian reactions}

By the early 20th century, foreign land holdings in Brazil were relatively limited. This gradually changed from the middle of the century, and with the inwards agricultural expansion from the 1970-1980s, foreign rural establishments increased markedly (Sauer \& Leite 2012, p.513). In 1971, foreign land purchases were regulated through law no.5.709, but its statutes were vague, and became subjected to many posterior alterations (BRAZIL Lei 5.709, 1971). Due to the intention of attracting foreign capital, the law was never implemented vigorously (Sauer \& Leite 2012, p.507). A constitutional amendment from 1995 eliminated the juridical distinction between national and foreign capital, which effectively exempted foreign land buyers from obtaining a special authorization (Nakatani et al., 2014, p.70). As the land rush intensified throughout the 1990s, land tenure conflict became widespread, affecting millions of peasants and resulting in violent clashes and fatalities throughout the country (Simmons 2005, p.308). Large-scale land deals involving both foreign and domestic agro-industrial conglomerates nonetheless accelerated from around 2008 (Pitta, Boechat \& Mendoça 2017; Sauer 2010, p.72-73).

In 2008, the Chinese Chongqing Grain Group signaled its intent to purchase 200.000 hectares of land for soy production in the Western region of the state of Bahia. This announcement drew much public attention, and preoccupations also rose within large parts of Brazilian agribusiness. In May 2010, the President of the Brazilian Association of Soy Producers (APROSOJA), Glauber Silveira, expressed concerns about the estimated 1 million hectares of land possessed by foreign individuals and capital funds. Silveira referred to Chinese investments as a threat to Brazilian producers, and highlighted the importance of maintaining national control of agricultural production (Um milhão de hectares já são de estrangeiros 2010). Resentment towards Chinese investment amongst both industrialists and the landed elite materialized in a joint campaign, highlighting their supposedly politically driven nature, and defending a tightening of regulation. These mobilizations' central figureheads were the Depute Homero Pereira, from the de-facto right-wing Partido da República, and former Minister of Finance, Delfim Neto. (Oliveira 2018, p.124).

The campaign against Chinese land purchases resonated strongly within Brazilian media outlets and produced a negative framing as part of the strategy to garner political support for regulatory action. In 2010, the newspaper Folha 
${ }^{2}$ Interview with Brazilian specialist in land tenure issues conducted by email, 15/4, 2018.

${ }^{3}$ Interview with Brazilian specialist in land tenure issues conducted by email, 15/4, 2018.

${ }^{4}$ Interview with Brazilian specialist in land tenure issues conducted by email, 15/4, 2018. de São Paulo described how foreign land purchases amounted to the equivalent territory to 22 football fields every hour, and referred to this development as a "foreign invasion" (Estrangeiros compram 22 campos de futebol por hora 2010). In an editorial text, the conservative newspaper Estadão expressed alarm about Chinese land purchases, which were associated with neo-colonialism, and cited Delfim Neto who stated that "after buying Africa, the Chinese are now attempting to buy Brazil" (China compra terras no Brasil 2010). The editorial piece highlighted the Chongqing Grain Group's attempted deal in West Bahia, and described it as part of a wider Chinese power-seeking strategy (Ibid). The campaign bought into broader narratives of Chinese global land grabbing, but also converged with dominant storylines within other business sectors about this Asian economy's negative economic impact on Brazil, giving voice to what has been referred to as a "anti-Chinese protectionism" (Powell 2012, p.201).

Increasing inflows of foreign capital into Brazilian agriculture had resulted in rising land prices, which frustrated many medium-sized producers who were too small to benefit from these investments through partnerships (Oliveira 2017, p.152-153). The president of the Brazilian Vegetable Oil Industry Association (ABIOVE) also expressed clear concerns regarding the Chinese investors, affirming that "they are looking for land, looking for reliable partners. But what they would like to do is run the show alone" (Chinas interest in Farmland makes Brazil Uneasy 2011). The fact that attempted Chinese land purchases gained so much negative attention compared other foreign land deals has also been attributed to circumstances such as local politics in Bahia, a negative bias within the press, ${ }^{2}$ and possibly also a degree of "sinophobia" (Oliveira 2018). An interviewee thus characterizes this as a "loose critique" based on "news stories" rather than "factual reporting". 3

The campaign against foreign land deals also included smallholder organizations and NGOs. In 2010, social movements organized a campaign to establish a general ceiling for rural property, with a strong emphasis on halting large-scale foreign land purchases (Sauer \& Leite 2012, p.520). William Clementino from the National Confederation of Agricultural Workers (CONTAG) thus argued that the "foreignization" of land did not constitute a viable development path, as it raised prices on rural property, and thereby obstructed land reform (Câmara dos Deputados 2011a). On the discursive level, these mobilizations pitted the notion of development through agro-industrial expansion against the principles of food security, sovereignty, and land reform (Castro, Hershaw \& Sauer 2017, p.92). Carlos Vicente, from the Spanish NGO, GRAIN, emphasized the negative implications of foreign land deals in Brazil in terms of perpetuating monoculture and augmenting vulnerability to speculative investment (Câmara dos Deputados 2011a). Prior to these mobilizations, left-leaning political factions and social movements supporting the incumbent Workers Party had similarly backed restrictions of foreign land purchases (Oliveira 2017, p.152). Coupled with dissatisfaction on behalf of smallholder segments with the Lula government's alleged lack of attention to land reform, and with the accelerating process of land concentration, such demands resonated strongly. ${ }^{4}$ Restrictive regulation on foreign land deals could thereby marry a reaffirmation of the government's support base with a strengthening of ties with groups within the highly politically organized agribusiness sector.

The negative public attention towards foreign land purchases eventually spurred the Lula administration to respond through restrictions in form of executive measures (Sauer 2010, p.73). The National Institute for Colonization and Agrarian Reform (INCRA), which is directly subjected to the presidency, therefore requested that the Attorney General of the Union (AGU) revised the legal decision GQ no.181 of 1998, which in effect averted control with land acquisition by foreign enterprises in Brazil (Sauer 2010, p.83). Furthermore, in 2010 
joint pressures by members of the presidential cabinet and Federal Public Ministry spurred the Attorney General to reinterpret the law no. 5.709 of 1971 on foreign land holdings towards a more restrictive understanding. The new version imposed stronger limits on land acquisitions by foreign individuals and enterprises, and for Brazilian companies with more than 50\% foreign capital, while requiring stricter registration of completed land acquisitions. It also prohibited foreign land acquisitions above 50 MEIs - a measure varying from 5-100 hectares depending on the municipality - and foreign possession of more than $25 \%$ of the territory of any single municipality (Câmara dos Deputados 2011b). Although the Attorney General, Luís Inácio Adams, stated that the decision was not directly aimed at limiting Chinese land purchases, he did take notice of Chinese land grabs in Latin America and Africa, underscoring that "nothing is preventing investment from happening, but it will be regulated" (Chinas interest in Farmland makes Brazil Uneasy 2011). This converges with dominant scholarly interpretations of the decision as a direct attempt to limit Chinese land acquisitions, (Pereira \& de Castro Neves 2011, p.6; Myers \& Jie 2015, p.16-17; Wilkinson \& Wesz 2013, p.255; Oliveira 2018; Powell 2012, p.206).

In spite of resistance from subsectors within Brazilian agriculture, the Chinese land investments were nonetheless defended by large swaths of Brazilian agribusiness. Moreira Mendes, leader of the agribusiness caucus in Congress, thus emphasized that restrictions on foreigners' land purchases would discourage investment, and that mechanisms to ensure sovereignty already were embedded within the Brazilian Constitution (Câmara dos Deputados 2011b). Similarly, Kátia Abreu, head of the National Confederation of Agriculture (CNA), defended international land investment as an important means to attract capital to sectors such as pulp, ethanol, and orange production, and claimed that resistance to foreign economic participation was due to "harmful entrenched preconceptions" in Latin America (Câmara dos Deputados 2011a). The CNA thereby continued to work in close conjunction with Chinese authorities and private sector representatives in order to attract them to invest in Brazilian agriculture, and in 2012 the entity organized public events with this purpose in mind (CNA quer investimentos chineses no agronegócio brasileiro 2012; Plano de Voo" 2012).

The reinterpretation of the law 5.709 meant that in spite of not being outright cancelled, the West Bahia land deal was stalled (Myers \& Jie 2015, p.11). Yet, due to the support for foreign land investment from the agribusiness caucus within Congress, the executive's steps towards tightening regulation were not followed up by legislative action (Las barreras a la extranjerización 2013). The measures to limit foreign land deals thereby became somewhat isolated and left some significant room for circumvention. Apart from the flexible definition of the permitted maximum for foreign land holdings, the INCRA did not dispose of effective fiscal mechanisms to monitor such deals (Sauer \& Leite 2012, p.521). Furthermore, President Dilma Rousseff, who assumed office in 2011, along with her Minister of Agriculture, Wagner Rossi, were also more inclined towards easing restrictions on international agricultural investments. Reports of foregone foreign investments of up to US $\$ 15$ billion therefore made Rossi raise the possibility of leasing land to potential global investors (Brazil mulls leasing farmland to foreigners 2011).

Rather than completely hampering Chinese interest in Brazilian agriculture, the legal restrictions appear to have reshaped Chinese commodity enterprises' strategies towards acquiring agricultural produce through predefined contracts with producers, and shifted attention towards the processing and logistics sub-sectors within the agro-industrial complex (Wilkinson \& Wesz 2013, p.255; Oliveira 2018, p.125). By 2013, reports by the Brazilian Intelligence 
Agency (ABIN) suggested that Chinese and Middle Eastern enterprises continued to acquire Brazilian farmland, through the use of strawmen (Estrangeiros já têm US\$ 60 bilhões em terra no Brasil 2013). This situation would latter spark attempts towards legislative changes in the direction of liberalization of land sales by the Temer Administration and the rural caucus in parliament, in early 2017. Thus, although fear of Chinese land grabbing did provide a certain momentum for regulatory measures to halt this development around 2010, since then, forces from within the agribusiness sector appear to have been keen on reversing these provisions.

\section{IV.2 Mobilizations against the Rio Negro deal in Argentina}

5 Extranjerización (in Spanish) describes a general trend of land grabs in different Latin American countries.
Although foreign land holdings have long been part of the Argentinean rural economic structure, an accelerated process of land investments began with the crisis of 2001-2002. The devaluation of the Argentinian peso from 2002 became a key factor in attracting foreign capital, which resulted in a large increase in the number and in the size of land transactions (Costantino 2016, p.139). This spelled the beginning of a period in which many international investors, including state-owned and semi-state enterprises from emerging nations, gained presence within the Argentinean agricultural sector (Andrieu \& Costantino 2017, p.90). The "foreignization" ${ }^{5}$ of lands became associated with rural conflicts, as agro-industrial development reached areas otherwise essential for the social reproduction of local communities (Ibid). This contention was further fueled by general popular dissatisfaction with the political system in the wake of the crisis, which resulted in a rejection of the neoliberal development trajectory of the 1990s.

Many transactions became centered on the province of Patagonia, which apart from low land prices also was seen as a relatively safe investment destination due to scarce population and resultantly perceived lower potential for conflict (Vazquez \& Sili 2017, p.134). Provincial authorities in Patagonia also sought to attract foreign investments. Meetings were held between the governor of Rio Negro, Miguel Saiz, and different Chinese entities, who stated their interest in investing in the region's agriculture (La pelea por la tierra 2011). Reports also suggest that these efforts enjoyed federal support, and that ministers of the former President Nestor Kirchner participated in the delegations which travelled to China to negotiate the deal (Costantino 2016, p.144). In 2010, Governor Saiz presented an agreement with the Chinese state-owned enterprise Heilongjiang Beidahuang. When presented, the deal had already been signed, and its content was held secret for the public during the negotiations (GRAIN 2011 , p.3). It implied the concession of some 320.000 hectares for production of soy, wheat, and oilseed rape, destined for the Chinese market (El Sindrome de China 2011). The initial investment of US $\$ 1.5$ billion would give Beidahuang priority to purchase production output over a 20 year period, and its outlay would be repaid with a 5\% annual interest rate. The deal was presented as distinct from a "sale" by governor Saiz, as it was based on contracts with local producers, rather than on acquisition of public lands, and he highlighted its alleged potential to create in the order of 100.000 jobs (Un acuerdo entre China y Río Negro genera polémica 2011). Local authorities generally acted in a very accommodative manner as a facilitator of the investment project, and appears to have been strongly motivated by the prospects of logistics development and land price increases (Costantino 2016, p.144).

The Rio Negro project eventually met critique from abroad range of local stakeholders. Mobilizations against the deal grew to comprise of diverse regional and national social organizations, indigenous peoples, students, scientists, labour unions, and local producers and neighbors to the lands in question ${ }^{6}$ 
${ }^{6}$ Interview with Argentinean NGO representative conducted by email, 26/4, 2018.
(Schilan 2012). Environmental specialists raised alarm regarding the deal's potential impact on a region with scarce water resources, and concerning the zoning of native forests, which made some refer to these plans as an "ecocide" (GRAIN 2011, p.4). The Argentinean NGO, Grupo de Reflexión Rural, also strongly criticized the introduction of large-scale agro-industrial farming in the region, and the concomitant dedication of local land resources to meeting food demand abroad (Ibid p.5). As the lower Rio Negro valley constitutes the historical homeland of the indigenous Mapuche, this community and the Indigenous Advisory Council (CAI) also became deeply engaged in the protests. The Mapuche was not consulted prior to the agreement, which led to claims that the constitutional statutes regarding indigenous people's rights had been violated (COHA 2011).

The framing of the agreement was strongly based on the notion of sovereignty and concerns for the national environmental and cultural heritage. These preoccupations were reflected in the title of a campaign launched by a local NGO, El Foro Permanente por una Vida Digna, which was dubbed, "No Soy, No China: land and food sovereignty for Argentina". The group strongly rejected the agreement, stressing that "we oppose the agro-export mega-project instrumentalized by the national and local government, which comprises of 320.000 hectares of soil and nature of Rio Negro to be handed over to the authority of the Chinese republic, which violates our sovereign laws, which institutes agriculture without farmers, which pollutes us with its pesticides, and which harms the present and future generations" (El Sindrome de China 2011).

The Pastoral Care Ministry of the Catholic Church also disproved of the concession of land to contract farming, stressing how it would jeopardize the future of the Rio Negro residents (GRAIN 2011, p.6). At a meeting in the city of Bariloche, the local Association of Biologists, along with students from different parts of the country issued a joint declaration of alert, denouncing the "implementation of an agro-industrial and transgenic production model" highlighting the risks for "the native flora and fauna and for the human population" (Río Negro: profesionales y estudiantes 2010). Local socio-environmental concerns were thus married with narratives of the preservation of national sovereignty. This served to establish a connection to storylines revolving around foreign exploitation, which prevailed in the post-neoliberal political period (Torrado 2016). By buying into nationalistic narratives, the opposition to the Rio Negro project both gained legitimacy, but also created pressures for action from the central political level, which had assumed a strongly sovereignty-focused discourse. This tactic appears to have been relatively successful, as the ruling Kirchnerismo's local branch, - which regionally constituted the opposition also became opposed to the agreement. The Minister of Agriculture, Julián Domínguez, also expressed his skepticism in similar terms, stressing that it "appeared as a complex task to live side by side with another sovereign state inside of our own” (Un acuerdo entre China y Río Negro genera polémica 2011).

President Cristina Kirchner was also pressed by the agribusiness interests in the Argentinean Agrarian Federation (FAA), which wanted regulation of foreign land acquisitions inserted within the legislative agenda. Deputy Pablo Orsolini, from the FAA, also presented the need to limit foreign land deals with a similar sovereignty-based emphasis, stressing that, "we cannot permit that Argentina becomes one of the only countries in the world where it is possible to buy land in unlimited quantities with complete swiftness and impunity" (Afirman que este año podría aprobarse la ley 2011). Although the Kirchner administration took some initial steps to regulate foreign land purchases, a significant amount of internal uncertainty about the appropriateness of this course of action became evident (Un acuerdo entre China y Río Negro genera polémica 2011). Thus, while announcing the intention to device a law regulating foreign land 
${ }^{7}$ Interview with Argentinean NGO representative conducted by email, 26/4, 2018 . purchases, Kirchner nonetheless highlighted the importance that this legislation would be tailored so as to avoid any anti-investment bias (Afirman que este año podría aprobarse la ley 2011). As stated by an Argentinean NGO representative, Kirchner sought to display concern for foreign land grabbing, without having to impose overtly restrictive regulation towards these investments, "I think that it was a way for the Kichner administration to show its awareness about the issue, without treating it in a more profound manner (...) the legal impediments eventually imposed for foreign land purchases were quiet limited". ${ }^{7}$ Kirchner's ambiguity about addressing foreign land deals should be viewed in light of the imperatives imposed by the development model pursued at the time. Thus, in spite of the political shift towards a more left-leaning government from 2003, the continued reliance on agricultural exports resulted in a political amalgam of social redistribution backed by commodity revenues, expressed as a "progressive neo-extractivism" (Cáceres 2015; Gudynas 2009) which often led economic considerations override socio-environmental concerns.

On April 27, 2011, the law no.26.737, which addressed foreign land acquisition was presented by President Kirchner. The law established a $15 \%$ limit for foreign land ownership on the national, provincial, and municipal level, and mandated that no more than $30 \%$ of lands in these entities could be owned by any single nationality. It also defined a ceiling of 1000 hectares for land ownership by foreign individuals or economic groups (Ley 26.737). The law has been criticized for not referring to environmental protections, or the rights of workers or the indigenous population, and for lacking a clear definition of foreign ownership (COHA 2011). Reports that foreign land investments continued through Argentinean investor societies also came to the public's attention in the following years (Vazquez \& Sili 2017, p.134). Facing prospects of continued transnational capital inflows into Argentinean agriculture, voices from the indigenous movement called for tighter regulation, that also would address the commodification of land (Las barreras a la extranjerización 2013). As the law no.26.737 did not have any retrospective effect, it did not affect the Rio Negro project. Yet, a ruling from the court in Rio Negro in November 2011 suspended the project on environmental grounds until adequate preventive and precautionary measures could be taken, which eventually led to its definitive cancellation. The ruling was hailed by groups opposed to foreign land investments as a historical precedent for Argentina and all of Latin America, and as an important measure in defense of national food sovereignty (La justicia frena inversión de China en Río Negro, 2011).

\section{IV.3 The "peaceful Chinese purchase" of land in Santa Cruz.}

During the 20th century, agricultural expansion in Bolivia has been driven by both internal migration and foreign land acquisition. The two-tracked agricultural development model pursued since the 1940s meant that migrants from the Bolivian highlands received plots of 20-50 hectares for cultivation of domestic food supplies in the lowlands, while capital-strong investors received large tracts between 500-50.000 hectares for export-oriented farming (McKay $\&$ Colque 2016, p.583). From the 1980s, efforts to pursue agro-industrial development were intensified through the Programa de Desarrollo de las Tierras Bajas del Este, comprising mechanization and productive specialization in grains and oilseeds (Urioste 2008, p.185). As part of this development, foreign agribusiness made incursions into the Bolivian lowlands, particularly the Santa Cruz province. Brazilian producers became strongly integrated within the Bolivian soybean complex, and from the early 1990s towards the harvest season of 2006-2007, they appropriated some $40 \%$ of the total area dedicated to soy production (Urioste 2012, p.447). Foreign land investments have thus become widespread in the Cruzeño soy sector (Bolivia: Más de un millón de hectáreas 
8 Interview with Bolivian NGO representative conducted by email, 9/5, 2018 .

9 Interview with Bolivian NGO representative conducted by email, 13/4, 2018.

${ }^{10}$ Interview with Bolivian NGO representative conducted by email, $9 / 5,2018$. en manos de extranjeros 2011), and large-scale deals reaching 100.000-200.000 hectares from Argentina, Japan, and Middle Eastern countries have also materialized (COHA 2011).

For most of the 20th century, the Bolivian regulatory environment for foreign land acquisitions was extremely permissive. Yet, the agrarian laws no. 1715 of 1996 and no.3545 of 2006, which subsequently were inscribed in article 396 of the Bolivian Constitution of 2009, explicitly prohibited the sale of land to foreigners by the state (Constitution Bolivia 2009; Ley no.1715:1996; Ley no.3545:2006). Land deals between private parties, though, could continue unhindered. Although a popular referendum had resulted in the constitutionalization of a 5000 hectare ceiling for foreign land ownership, agribusiness pressures led to a provision which permitted an unrestricted number of associations to each hold 5000 hectares, which essentially invalidated the land ceiling (McKay \& Colque 2016). Furthermore, lack of public oversight meant that until 2010, large cultivated areas were unregistered (Bolivia: Más de un millón de hectáreas en manos de extranjeros 2011).

In the 2000s, this legal milieu provided a fertile context for land acquisition by foreign investors. In 2005, the Chinese Shanghai Pengxin Group purchased 12.500 hectares in the Santa Cruz province which were dedicated to soy, sorghum, and maize production, at the price of US\$27 million (GRAIN, 2016). The Pengxin Group engages in a great variety of activities, and apart from agriculture, its sub-branches span from infrastructure, to textile production and research (A partir del interconectado se plantea una etapa de desarrollo 2010). Although the Pengxin Group often has been associated with the Chinese government's ' going out' policy, the decision to invest in Bolivia has likely been made independently by the company (Jie \& Myers 2016, p.106). This is convergent with a trend of increasingly market-based investment by Chinese private, state-owned, and provincial companies in the 2000s (Myers 2013). In contrast to other major land deals involving Chinese actors in South America, the Pengxin agreement did not incite significant negative reactions ${ }^{8}$. Although the Bolivian NGO Fundación Tierra publicly contested the deal as violating the constitutional ceiling of 5000 hectares, the issue did not gain salience within the public sphere 9 . Strong reactions, which did otherwise usually accompany extractive investments in oil, natural gas, and infrastructure projects in Bolivia did thereby not result from the deal with the Chinese Pengxin Group, which to some extent, went relatively unnoticed ${ }^{10}$. This warrants analysis of the domestic sources of potential contestation, which in the other cases of land deals examined reacted differently to Chinese land purchases.

Positioned at the margins of agro-industrial transformations, smallholders reactions become particularly relevant to analyze, because a latent potential for contestation oftentimes can be found within these segments. Yet, the particular configuration of capital within the rural productive organization in Santa Cruz nonetheless seems to have discouraged smallholder protest against the advance of agribusiness. Due to lack of capital, small farmers have been unable to engage in soy production, which has made them rent their land to larger soy producers. As petty bourgeoisie rentiers, many do not identify with the landless peasant movement, and have therefore not wanted to challenge the development of the soy complex, in spite of their essential exclusion from the productive activities within this. (McKay \& Colque 2016) Thus, the Cruceño smallholders' "adverse incorporation in the soy complex has impeded overt forms of resistance" (McKay 2017a).

Considering the cases from Brazil and Argentina, domestic agribusiness could be considered as another potential source of contestation of the Chinese incursions into Bolivian agriculture. Yet, the presence of international investors 
${ }^{11}$ Interview with Bolivian NGO representative conducted by email, 13/4, 2018 .

${ }^{12}$ Interview with Bolivian NGO representative conducted by email, 13/4, 2018.

${ }^{13}$ Interview with Bolivian NGO representative conducted by email, 13/4, 2018 .

${ }^{14}$ Interview with Bolivian NGO representative conducted by email, May 9, 2018. has nevertheless been well received by Cruceño elites. As foreign agribusiness brings capital and access to knowhow and new market opportunities, dominant classes have not sought to obstruct its entry (Urioste 2012, p.453). Local cattle ranchers, which hold a large proportion of uncultivated areas, have benefitted from selling or renting their land to foreign investors (Urioste 2012, p.452). The same openness to foreign investment appears to characterize Bolivian soy producers, who have encouraged this as an important source of input provision and technical modernization (McKay 2018). Cooperative relations thereby appear to characterize the manner that land-holding classes in Santa Cruz have engaged with foreign agricultural investors, as is highlighted by an interviewee from a Bolivian NGO "In general the agribusiness and landholding elites are very positively minded towards the capital flows towards the agricultural sector in Santa Cruz. The landholders are strongly opposed to every law that might restrict the purchases of land on behalf of foreigners."

Finally, the Bolivian state does not appear particularly skeptical towards agro-industrialization, nor very proactive in limiting this development. Thus, despite a discursive distancing from the Latifundio and agribusiness, the state has often facilitated foreign land acquisitions (Bolivia: Más de un millón de hectáreas en manos de extranjeros 2011). An NGO representative even describes foreign land purchases as a "taboo", oftentimes avoided within public discourses ${ }^{12}$. The Morales government has furthermore been active in promoting the proliferation of an agro-industrial rural development model, with extensive plans aiming towards the annual expansion of the agricultural frontier of around 1 million hectares (McKay 2017a). The state has furthermore been criticized for adopting a rather permissive stance towards illegal land transfers (Sugieren leyes que prohíban venta de tierras 2011). This becomes reflected by the fact, that there have been no serious attempts at clearly registering foreign land acquisitions within public records ${ }^{13}$. Official rhetoric, revolving around narratives of "agrarian revolution" or "food sovereignty", has thus increasingly diverged from the effectively pursued policies of "reconstituated neo-liberalism", which lead to marginal changes but no structural transformation of the economy (McKay \& Colque 2016, p.588). This also includes either the cooption of social movements, or the introduction of severe punishment for land occupations, which constitute peasant movements' main instrument of resistance (McKay \& Colque 2016 pp.605-606).

Despite the absence of major protests in the Santa Cruz province, some voices on the national level did speak in favor of tighter regulation of foreign land acquisitions. In 2011, former land minister Alejandro Almaraz stressed the need to restrict land sales to foreigners, and to keep clearer records of land holdings (Sugieren leyes que prohíban venta de tierras 2011), - an objective that was backed by different social movements (Encuentro Plurinacional en su etapa definitoria 2012). Eventually, in December 2013, the law no.477 "against land subjection and trafficking" was passed. Yet, rather than introducing any significant new measures to limit foreign land acquisitions, the law established stricter punishments, ranging between 3-8 years of prison for illegal appropriation and sale of public lands, which already was enshrined in the Bolivian Constitution. The law also banned official recognition of foreign owned land which did not serve an economic social purpose (Ley no. 477:2013). Law no. 477 appears most significant in terms of regulating existing foreign rural land possessions in Bolivia, while still keeping a window open for international investment. The harsh punishments which it contained may indeed have served the interest of land holders ${ }^{14}$, as they also applied to land occupations conducted by peasant movements. So, in contrast to cases in Argentina and Brazil, the law did not materialize due to fears of increased Chinese land acquisition, neither did it significantly halt foreign land deals. After the law was passed, the Confederation of 
Rural Workers of Bolivia (CSUTCB) and the Confederation of Intercultural Communities of Bolivia (CCIB) continued to push for restrictions of foreign land purchases. Gustavo Aliaga from the CCIB thus underscored that regulations still favored foreigners more than Bolivian producers, while Rodolfo Machaca from the CSUTCB claimed that Brazilian, Chinese, and Russian land grabbers continued unhindered (Piden que el Gobierno elimine la extranjerización de tierras 2014).

\section{Conclusions and Discussion of Chinese land deals in South America}

The processes through which domestic groups reacted to attempted Chinese land grabs in the three South American countries analyzed are marked by some distinctive features as well as common traits. Their outcomes nonetheless vary, as the Chinese land deal in Bolivia did not meet significant opposition, and neither did it contribute to regulatory changes. In both Brazil and Argentina, the forces opposing these agreements were relatively heterogeneous. The resistance movement to the Rio Negro project assumed a networked (Rocheleau 2015) structure, comprising of a diverse array of civil society actors. Although opposition to foreign land deals in both Argentina and Brazil comprised of certain agribusiness branches and different social movements, these forces appear to have mobilized in separate tracks, due to widely differing motivations. Agribusiness' support for legal restrictions to foreign land investments became very significant in spurring regulatory change in Brazil; possibly more so than in Argentina, where protests by local social movements gained a strong momentum. In similarity with Baird (2014), in both Argentina and Brazil, a national sovereignty-focused discourse was selectively appropriated by agribusiness elites in their efforts to negatively frame these attempts. The lack of incentives by the Cruceño elites, and the absence of viable means and immediate reasons for smallholder segments to oppose the Pengxin Group's land purchase in Santa Cruz seems to have become evident. In line with the logic of the most similar case design, the different composition of agribusiness capital and variations in the socioeconomic structure in this region thereby appears to constitute a central explanatory factor in accounting for the non-materialization of protest in the Bolivia case.

Resistance to Chinese land deals was expressed through different avenues. The "official politics" mode of protest (Kerkvliet 2009), referring to a cooperative approach in relation to authorities, appears to have characterized domestic agribusiness engagement in Brazil and Argentina. A more conflictive engagement through "advocacy politics" has constituted the preferred mode of protest in the Argentinean social mobilizations. The manner in which the Chinese land deals were framed in public debate appears to have been a central factor in defining the subsequent legislative responses. In Brazil, the negative framing revolving around a "takeover", - with references to Chinese land grabs in Africa, emanated mainly from parts of the rural elite and groups within the political and economic intelligentsia, and attracted much attention within national media. The strong grassroots linkages of the Rio Negro campaign in Argentina meant that a discursive amalgam was produced, as local socio-environmental concerns were coupled with nationalistic sovereignty-focused narratives. In Bolivia, a significant dissonance between official discourse revolving around self-determination of local peoples, and effectuated policy, meant that the legislation introduced in 2013 fell short of restricting foreign land deals, and even might have strengthened agribusiness vís-a-vís smallholder segments.

The magnitude of the manifestations against the Chinese deals may appear remarkable, considering their relatively modest extent compared to investments from other countries. The backlashes which they generated, and the accusations 
of "neo-colonial behavior", even appear to have dampened Chinese interest in land investments (Myers 2013; Myers \& Jie 2015, p.8). The strong global attention surrounding the internationalization of Chinese enterprises, and the cloud of uncertainty with respect to its potential scale and implications, might well have spurred fears within the Brazilian and Argentinean agricultural sectors, which were not awoken in relation to larger land deals with developed country companies. While the Bolivian deal was signed by the private Pengxin Group, the acquisitions in Brazil and Argentina were sought effectuated by state-owned enterprises. This may also have nurtured existing speculations and worries about any potential secondary motivations with these agreements. The question of whether Chinese investments are driven by official strategies and non-market related geopolitical concerns (Chi 2010, p.108; Albuquerque \& Lima 2016, p.579; Wang et al., 2013) also appears to have been central to the debates about how to meet this development. The fact that the attempted deals in Brazil and Argentina were Chinese thereby appears to have left a window of opportunity for both elites and social groups that already were skeptical or directly opposed towards foreign land purchases, to gain some voice at the political level, which resulted in a certain measure of regulatory action.

The different domestic responses to Chinese land deals should also be viewed in light of the structural position of each country within the global political economy of agriculture. The status of Argentina and Brazil as New Agricultural Countries (NACs) (Friedmann 1992) can be viewed as an intermediate position, whereby both receive large amounts of investments, but still retain a noticeable concentration of domestic capital within certain agricultural subsectors, and in specific links within the agro-food chains. While in Brazil, there is a strong foreign presence within the agro-industrial complex (Albano \& De Sá 2011, pp.63-64; Schlesinger 2008, p.9), direct cultivation is mainly dominated by domestic producers (Hopewell 2013, p.608). Chinese expansion into direct production has thereby likely generated fears of rising land prices amongst Brazilian farmers (Oliveira 2018), which explains the worries expressed by some Brazilian agricultural producers. This converges with Thaler's (2014, p.832) observation that middle-income semi-peripheral countries, with capital-intensive agricultural sectors, are more likely to reject large-scale land deals than poorer countries, with less capital and a larger need for external revenue generation. The present conclusions thereby strongly highlight rural production structures and their international connectedness as the principal explanatory point of departure for understanding the varying reactions to Chinese land purchases. Although the Chinese presence within the agricultural sector is more open to negative framings than are other investments, motivations to either oppose or consent to these agreements should be found within existing rural divisions, and the historically defined latent conflict potential of contentious land issues.

The different ways in which the Brazilian, Argentinean, and Bolivian states have mediated the pressures for and against Chinese land grabs also reflect a division between an attentiveness to certain social and sectorial concerns, and a clear interest in commodity-related investments. The systemic imperatives pushing the state towards facilitating natural resource based development constitutes an element of continuity between the neo-liberal period of the 1990s, and the post-liberal period of the 2000s and early 2010s (Vazquez \& Sili 2017, p.120). The structural power of agribusiness therefore means that regulation of this sector is associated with high political costs. The support from swaths of Argentinean and Brazilian agribusiness has thereby been decisive in order to permit the regulatory measures taken within this area. It thus becomes difficult to identify the laws passed to restrict foreign land grabs as part of a more fundamental Polaniyan double movement (Cotula 2013) towards social regulation of 
land markets. The legal measures taken in a context of strong attention towards Chinese land grabbing thereby appear more as a momentary impulse, than as a more fundamental step to address rural inequalities.

Niels Søendergaard (NielsS@insper.edu.br) has a PhD in International Relations from the International Relations Institute of the University of Brasília and is currently researcher at the Insper Agro Global.

\section{References}

Andrieu, J. \& Costantino, A. (2017) La tierra como acervo de bienes comunes. Los conflictos sociales sobre bienes comunes ligados a la extranjerización de la tierra en la Argentina reciente. Eutopia, s/v(11), pp.77-94.

Albano, G.P. \& De Sá, A.J. (2011) Globalizacão da Agricultura: Multinacionais no Campo Brasileiro. Revista de Geografia (UFPE), 28(1), pp.54-80.

Aldrich, S., Walker, R., Simmons, C., Caldas, M. \& Perz, S. (2012) Contentious Land Change in the Amazon's Arc of Deforestation. Annals of the Association of American Geographers, 102(1), pp.103-128.

Albuquerque, J.A.G. \& Lima, L.A.F. (2016) Chinese Investment in Brazil: Can It Match the Relevance of Bilateral Trade? Asian Perspective, 40(4), pp.579-601. DOI: 10.1353/apr.2016.0026

Anseeuw, W. \& Taylor M. (2014) Factors shaping the global land rush. In: A. Reid Ross (ed). Grabbing back: essays against the global land grab. Oakland: AK Press, pp.45-60.

Baird, I.G. (2014) The Global Land Grab Meta-Narrative, Asian Money Laundering and Elite Capture: Reconsidering the Cambodian Context. Geopolitics, 19(2), pp.431-453. DOI: 10.1080/14650045.2013.811645

Borras Jr., S.M., \& Franco, J. (2010) Towards a broader view of the politics of global land grab: rethinking land issues, reframing resistance. Initiatives in Critical Agrarian Studies Working Paper Series. Available through: <http://ramshorn.ca/sites/ramshorn.ca/files/Borras \&Franco,PoliticsofLand Grab.pdf>

Brent, Z.W., Alonso-Fradejas, A., Colque, G. \& Sauer, S. (2018) The "tenure guidelines" as a tool for democratising land and resource control in Latin America. Third World Quarterly, 39(7), pp.1367-1385. DOI: 10.1080/01436597.2017.1399058

Cáceres, D.M. (2015) Accumulation by Dispossession and Socio-Environmental Conflicts Caused by the Expansion of Agribusiness in Argentina. Journal of Agrarian Change, 15(1), pp.116-147. DOI: 10.1111/joac.12057

Castro, L.F.P., Hershaw, E. \& Sauer, S. (2017) Estrangeirização e internacionalização de terras no Brasil: oportunidades para quem? EstudosInternacionais, 5(2), pp.74-102. DOI: 10.5752/P.2317-773X.2017v5n2p74

Castro, L.F.P. \& Igreja, R.L. (2017) Estrangeirização de Terras na Perspectiva das Pormas de Colonialidade no Agro Latino-Americano. Revista de estudos e pesquisa sobre as Américas, 11(2), pp.164-179.

Chi, L. (2010) Opportunity for Economic Expansion. In: L. Chi (ed). China After the Subprime Crisis. Houndmills: Pelgrave Mcmillan, pp. 106-122.

Costantino, A. (2016) El capital extranjero y el acaparamiento de tierras: conflictos sociales y acumulación por desposesión en Argentina. Foreign Capital and Land Grabbing: Social Conflicts and Accumulation by Dispossession in Argentina., 55(1), pp.137-149. DOI: 10.7440/res55.2016.09

Cotula, L. (2013) The New Enclosures? Polanyi, international investment law and the global land rush. Third World Quarterly, 34(9), p.1605-1629. DOI: 10.1080/01436597.2013.843847Y

Edelman, M. (2013) Messy hectares: Questions about the epistemology of land grabbing data. Journal of Peasant Studies, 40(3), pp.485-501. DOI: 10.1080/03066150.2013.801340

Edelman, M., Oya,C. \& Borras, S.M., 2013. Global Land Grabs: Historical processes, theoretical and methodological implications and current trajectories. Third World Quarterly, 34(9), p.1517-1531. DOI: 10.1080/01436597.2013.850190

Flexor,G. \& Leite, S.P. (2017) Land market and land grabbing in Brazil during the commodity boom of the 2000s. Contexto Internacional, 39(2), pp. 393-420. DOI: 10.1590/s0102-8529.2017390200010

Friedmann, H. (1992) Distance and durability: Shaky foundations of the world food economy. Third World Quarterly, 13(2), pp.371-383. DOI: 10.1080/01436599208420282

George, A. \& Bennett, A. (2005) Case Studies and Theory Development in the Social Sciences. Cambridge: MIT Press.

Gudynas, E. (2009) Diez tesis urgentes sobre el nuevo extractivismo: contextos y demandas bajo el progresismosudamericano actual. In: A. Schuldt, A. Acosta, A. Barandiarán, A. Bebington \& M. Folchi, (eds). Extractivismo política y sociedad. Quito: CAAP/CLAES, pp.187-225.

Hall, R., Edelman, M., Borras, S.M., Scoones, I., White, B. \& Wolford,W. (2015) Resistance, acquiescence or incorporation? An introduction to land grabbing and political reactions "from below." Journal of Peasant Studies, 42(3-4), pp.467-488. DOI: $10.1080 / 03066150.2015 .1036746$

Hopewell, K. (2013) New Protagonists in Global Economic Governance: Brazilian Agribusiness at the WTO. New Political Economy, 18(4), pp. 603-623. DOI: 10.1080/13563467.2013.736957

Jie, G. \& Myers, M. (2016) Chinese agricultural investment in Latin America. Less there than meets the eye? In: M. Myers \& C. Wise (eds). The political economy of China-Latin American relations in the new millennium: Brave new world. New York: Routledge, pp. 143-196.

Kerkvliet, B.J.T. (2009) Everyday politics in peasant societies (and ours). Journal of Peasant Studies, 36(1), pp.227-243. DOI: 10.1080/03066150902820487 
Mamonova, N., 2015. Resistance or adaptation? Ukrainian peasants' responses to large-scale land acquisitions. Journal of Peasant Studies, 42(3-4), pp.607-634. DOI: 10.1080/03066150.2014.993320

McAllister, K.E. (2015) Rubber, rights and resistance: the evolution of local struggles against a Chinese rubber concession in Northern Laos. Journal of Peasant Studies, 42(3-4), pp.817-837. DOI: 10.1080/03066150.2015.1036418

McKay, B. (2017) The politics of convergence in Bolivia: social movements and the state. Third World Quarterly, 39(7), pp.1247-1269. DOI: 10.1080/01436597.2017.1399056

McKay, B. (2018) Control grabbing and value-chain agriculture: BRICS, MICs and Bolivia's soy complex. Globalizations, 15(1) pp.74-91. DOI: 10.1080/14747731.2017.1374563

McKay, B. \& Colque, G. (2016) Bolivia's soy complex: the development of "productive exclusion.” Journal of Peasant Studies, 43(2), pp.583-610. DOI: 10.1080/03066150.2015.1053875

Moreda, T. (2015) Listening to their silence? The political reaction of affected communities to large-scale land acquisitions: insights from Ethiopia. Journal of Peasant Studies, 42(3-4), pp.517-539. DOI: 10.1080/03066150.2014.993621

Myers, M. (2013) China's Agricultural Engagement in Latin America. The Inter-American Dialogue [online]. Available through: https://chinaandlatinamerica.com/2013/11/19/chinas-agricultural-engagement-in-latin-america-2/. Accessed at: 25.mar.2018.

Myers, M. \& Jie, G. (2015) Chinas Agricultural Investment in Latin America: A critical assessment. China and Latin America Report. The Dialogue. Aonline]. Available from: http://www.thedialogue.org/wp-content/uploads/2015/06/Chinas-Agricultural-Investment-in-Latin-America.pdf

Nakatani, P., Faleiros, R.N., Vargas, N.C., Felipe, P.C.N., Gomes, H. \& Trindade, R.V. (2014) A Expansão Internacional da China através da Compra de Terras no Mundo. Textos e Contextos, 13(1), pp.58-73. DOI: 10.15448/1677-9509.2014.1.15489

Oliveira, G.L.T. (2016) Regularização fundiária e a "corrida mundial por terras" no Brasil. Câmpo-Território: Revista de Geografía Agrária, 11(23), pp.43-75. DOI: 10.14393/RCT112302

Oliveira, G.L.T. (2017) The South-South Question: Transforming Brazil-China Agroindustrial Partnerships. PhD Dissertation. Berkeley: University of Berkeley.

Oliveira, G.L.T. (2018) Chinese land grabs in Brazil? Sinophobia and foreign investments in Brazilian soybean agribusiness. Globalizations, 15(1), pp.114-133. DOI: 10.1080/14747731.2017.1377374.

Pereira, C. \& de Castro Neves, J.A. (2011) Brazil and China: South-South Partnership or North-South Competition? Foreign Policy at Brookings. Policy Paper 26 [online]. Available through: https://www.brookings.edu/research/brazil-and-china-south-south-partnership-or-north-south-competition/\%5Cnpaper s3://publication/uuid/85C6D2B9-112E-41E3-B0C2-DC52DBD042AA

Pitta, F.T., Boechat, C.A. \& Mendonça, L.M. (2017) A produção do espaço na região do MATOPIBA: violência, transnacionais imobiliárias agrícolas e capital fictício. Estudos Internacionais, 5(2), pp.155-179. DOI: 10.5752/P.2317-773X.2017v5n2p155

Powell, E.D. (2012) Las relaciones económicas entre China y Brasil: ¿muy grandes para fracasar? Apuntes:Revista de ciência sociales, 38(71), pp.189-215. DOI: 10.21678/apuntes.71.665

Rocheleau, D.E. (2015) Networked, rooted and territorial: green grabbing and resistance in Chiapas. Journal of Peasant Studies, 42(3-4), p.695-723. DOI: 10.1080/03066150.2014.993622

Sauer, S. (2010) Demanda mundial por terras: "land grabbing" ou oportunidade de negócios no Brasil? Revista de Estudos e Pesquisas sobre as Américas, 4(1), pp.72-88.

Sauer, S. \& Borras, S.J. (2016) ‘Land Grabbing’ e `Green Grabbing’: Uma leitura da `corrida na produção acadêmica’ sobre a apropriação global de terras. Câmpo-Território: Revista de Geografía Agrária, 11(23), pp.6-42. DOI: 10.14393/RCT112301

Sauer, S. \& Leite, S.P. (2012) Expansão agrícola, preços e apropriação de terra por estrangeiros no Brasil. Revista de Economia e Sociologia Rural, 50(3), pp.503-524. DOI: 10.1590/S0103-20032012000300007

Schilan, R. (2012) Colonias del Siglo XXI: alimentos, especulación y arrebato territorial. Geografía Humana General 2012, textos unidad 4, pp.1-5.

Schlesinger, S. (2008) Soja: el grano que sigue creciendo. Grupo de Trabajo sobre Desarrollo y Medio Ambiente en las Américas. Trabajo de Discusión No.21, pp.1-23. Available through: $<$ https://docplayer.es/13161823-Grupo-de-trabajo-sobre-desarrollo-y-medio-ambiente-en-las-americas.html>. Accessed at: 02 mar. 2018.

Schneider, A. (2011) What shall we do without our land? Land Grabs and Resistance in Rural Cambodia. International Conference on Global Land Grabbing. Sussex. Available through: $<$ https://landmatrix.org/media/uploads/alison_schneider.pdf> Accessed at: 02 mar. 2018.

Scoones, I., Hall, R., Borras, S.M., White, B. \& Wolford, W. (2013) The politics of evidence: Methodologies for understanding the global land rush. Journal of Peasant Studies, 40(3), pp. 469-483. DOI: 10.1080/03066150.2013.801341

Simmons, C.S. (2005) Territorializing land conflict: Space, place, and contentious politics in the Brazilian Amazon. GeoJournal, 64(4), pp.307-331. DOI: 10.1007/s10708-005-5809-x

Smalley, R., \& Corbera, E. (2012) Large-scale land deals from the inside out: Findings from Kenya's Tana Delta. Journal of Peasant Studies, 39(3-4), pp.1039-1075. DOI: 10.1080/03066150.2012.686491

Temper, L. (2018) From boomerangs to minefields and catapults: dynamics of trans-local resistance to land-grabs. Journal of Peasant Studies, 46(1), pp.118-216. DOI: 10.1080/03066150.2017.1398144 
Thaler, G. (2014) The Twenty-First Century Agricultural Land Rush. In: R.J. Herring (ed). The Oxford Handbook of Food, Politics, and Society. Oxford: Oxford University Press. DOI: 10.1093/oxfordhb/9780195397772.013.017

Torrado, M. (2016) Food Regime Analysis in a Post-Neoliberal Era: Argentina and the Expansion of Transgenic Soybeans. Journal of Agrarian Change, 16(4), pp.693-701. DOI: 10.1111/joac.12158

Urioste, M. (2008) Evolución y características del sector soyero en Bolivia. In: X. Soruco, W. Plata, and G. Medeiros (eds). Los barones del oriente. Santa Cruz: Fundación Tierra, pp.173-240.

Urioste, M. (2012) Concentration and "foreignisation" of land in Bolivia. Canadian Journal of Development Studies/Revue canadienne d'études du développement, 33(4), pp.439-457. DOI: 10.1080/02255189.2012.743878

Vazquez, A. \& Sili, M. (2017) Dinámica espacial del proceso de extranjerización de latierra en la Patagonia. Journal of Latin American Geography, 16(2), pp.117-137. DOI: 10.1353/lag.2017.0024

Wells-Dang, A. (2010) Political space in Vietnam: a view from the riceroots. The Pacific Review, 23(1), pp. 93-112. DOI: 10.1080/09512740903398355

Wang, Y., Faria, M.D., Carvalho, J.L.F. (2013) Investimento Externo direto Chinês no Brasil: Motivações Desafios e Perspectivas. Internext: Revista Eletrônica de Negócios Internacionais, 8(2), pp.1-21.

White, B., Borras, S.M., Hall, R., Scoones, I. \& Wolford,W. (2012) The new enclosures: Critical perspectives on corporate land deals. Journal of Peasant Studies, 39(3-4), p.619-647. DOI: 10.1080/03066150.2012.691879

Wilkinson, J. \& Wesz Jr., V.J. (2013) Underlying issues in the emergence of China and Brazil as major global players in the new South-South trade and investment axis. International Journal of Technology Management \& Sustainable Development, 12(3), pp.245-260. DOI: 10.1386/tmsd.12.3.245_1

World Bank (2011) Rising Global Interest in Farmland. Agriculture and Rural Development Series. Washington D.C.: The World Bank.

\section{Newspaper and Blog Articles}

A partir del interconectado se plantea una etapa de desarrollo (2010) TiempoSur [online]. 21.dec. Santa Cruz. Available through: <https://www.tiemposur.com.ar/nota/19702-a-partir-del-interconectado-se-plantea-una-etapa-de-desarrollo-.html>. Accessed at: 17 mar. 2018.

Chinas interest in Farmland makes Brazil Uneasy (2011) New York Times [online]. New York, 26.Apr. Available through: $<$ http://www.nytimes.com/2011/05/27/world/americas/27brazil.html>. Accessed at: 10 mar. 2018.

Sugieren leyes que prohíban venta de tierras agrícolas a extranjeros (2011) Bolivia Rural [online]. 21.dec. Available through: $<$ http://www.boliviarural.org/noticias/2011/1250-sugieren-leyes-que-prohiban-venta-de-tierras-agricolas-a-extranjeros.htmb. Accessed at:18 mar. 2018.

Bolivia: Más de un millón de hectáreas en manos de extranjeros (2011) Bolpress [online]. 28.mar. Available through: $<$ https://www.bolpress.com/?Cod=2011032817>. Accessed at: 17 mar. 2018.

COHA, Council of Hemispheric Affairs (2011) A Land-Grabber's Loophole [online]. 8.aug. Available through: <http://www.coha.org/a-land-grabbers-loophole/>. Accessed at: 15 mar. 2018.

China compra terras no Brasil (2010) O Estado de São Paulo [online]. São Paulo, 3.Aug. Available through: $<$ http://opiniao.estadao.com.br/noticias/geral,china-compra-terras-no-brasil-imp-,589697>. Accessed at: 10 mar. 2018.

GRAIN (2008) Seized! The 2008 land grab for food and financial security. Grain Briefing October 2008. Barcelona.

GRAIN (2011) New Agricultural agreement in Argentina: a land grabbers “instruction manual”. Against the Grain. 25.jan.

GRAIN (2016) The Global Farmland Grab in 2016: how big how bad? Grain. Against the Grain. Barcelona. Available through: <https://www.grain.org/article/entries/5492-the-global-farmland-grab-in-2016-how-big-how-bad>. Accessed at: 10 mar. 2018.

Un acuerdo entre China y Río Negro genera polémica (2011) La Nación [online]. 28.aug. Available through: <https://www.lanacion.com.ar/1401319-un-acuerdo-entre-china-y-rio-negro-genera-polemica>. Accessed at: 16 mar. 2018.

Plano de Voo": CNA quer chineses nas terras do Brasil (2012) Diário de Indústria Comércio e Serviços [online]. 28.nov. Available from: <https://www.dci.com.br/opiniao/plano-de-voo/plano-de-voo-cna-quer-chineses-nas-terras-do-brasil-1.428571>. Accessed at: 28 nov. 2018.

La pelea por la tierra: Una empresa estatal de China quiere comprar 200 mil hectáreas (2011) La política online [online]. 11.mar. Available through: <http://www.lapoliticaonline.com/nota/50726/>. Accessed at: 15 mar. 2018.

Afirman que este año podría aprobarse la ley que restringe la venta de tierras a extranjeros (2011) La Política Online [online]. 3.mar. Available through: <http://www.lapoliticaonline.com/nota/nota-71682/>. Accessed at: 16 mar. 2018.

La justicia frena inversión de China en Río Negro (2011) La Política Online [online]. 23.nov. Available through: $<$ http://www.lapoliticaonline.com/nota/57168/>. Accessed at: 17 mar. 2018.

El Sindrome de China: la crescente presencia china en América Latina (2011) farmlandgrab.org [online]. 17.apr. Available through: <https://www.farmlandgrab.org/post/view/18478>. Accessed at: 25 mar. 2018.

Estrangeiros já têm US\$ 60 bilhões em terra no Brasil (2013) UOL Notícias [online]. 20.jan. Available through: $<$ https://colunaesplanada.blogosfera.uol.com.br/2013/01/20/estrangeiros-ja-tem-us-60-bilhoes-em-terras-no-brasil/>.

Accessed at: 25 mar. 2013. 
Brazil mulls leasing farmland to foreigners (2011) Reuters [online]. 9.may. Available through: <https://www.reuters.com/article/us-brazil-land/brazil-mulls-leasing-farmland-to-foreigners-idUSTRE74856K20110509>. Accessed at: 25 mar. 2011.

Estrangeiros compram 22 campos de futebol por hora (2010) Folha de São Paulo [online]. São Paulo, 02.nov. Available through: <http://www1.folha.uol.com.br/fsp/poder/po0211201002.htm>. Accessed at: 09 mar. 2018.

Río Negro: profesionales y estudiantes de Biología rechazan la producción de soja en la provincia (2010) Puertae - Colectivo de noticias [online]. 28.out. Available through: <http://puertae.blogspot.com.br/2010/10/rio-negro-profesionales-y-estudiantes.html>. Accessed at: 15 mar. 2018.

Las barreras a la extranjerización de la tierra tienen sus agujeros (2013) El País [online]. 18.apr. Available through: $<$ http://blogs.elpais.com/eco-americano/2013/04/las-barreras-a-la-extranjerizaci\%C3\%B3n-de-la-tierra-tienen-sus-agujeros.html > . Accessed at: 15 mar. 2018.

Food scarce sparks Third World land rush (2009) Reuters [online] 29.apr. Available through: $<$ https://uk.reuters.com/article/uk-agriculture-landgrab/food-scare-sparks-third-world-land-rush-idUKTRE53S97420090430>. Accessed at:19 mar. 2018.

Encuentro Plurinacional en su etapa definitoria (2012) El Día [online]. 9.jan. Available through: $<$ https://www.eldia.com.bo/mobile.php?cat=150\&pla=7\&id_articulo=82610>. Accessed at: 25 mar. 2018.

Um milhão de hectares já são de estrangeiros, diz Glauber Silveira (2010) Olhardireito [online]. 18.Abr. Available through: <http://www.olhardireto.com.br/noticias/exibir.asp?id=103280>. Accessed at: 20 mar. 2018.

CNA quer investimentos chineses no agronegócio brasileiro (2012) Terra [online]. 27.nov. Available from: $<$ https://www.terra.com.br/economia/cna-quer-investimentos-chineses-no-agronegocio-brasileiro,1e18b781eab41410 VgnCLD200000bbcceb0aRCRD.html>. Accessed at: 15 mar. 2018.

Piden que el Gobierno elimine la extranjerización de tierras (2014) Página Siete [online]. 3.mar. Available through: $<$ http://www.paginasiete.bo/nacional/2014/3/4/piden-gobierno-elimine-extranjerizacion-tierras-15393.html>. Accessed at: 17 mar. 2018.

\section{Other Sources}

AEI - American Enterprise Institute (2018) China Global investment Tracker. Available through: <http://www.aei.org/china-global-investment-tracker/>. Accessed at: 03 may. 2018.

Câmara dos Deputados (2011a). Trabalhadores e ruralistas divergem sobre investimento estrangeiro [online]. 25.jul. Available through: <http://www2.camara.leg.br/camaranoticias/noticias/AGROPECUARIA/200265-TRABALHADORES-E-RURALIST AS-DIVERGEM-SOBRE-INVESTIMENTO-ESTRANGEIRO.html:. Accessed at: 14 mar. 2018.

Câmara dos Deputados (2011b) Restrição à compra de terras por estrangeiros é prioridade de comissão [online]. 25.jul. Available through: <http://www2.camara.leg.br/camaranoticias/noticias/AGROPECUARIA/200262-RESTRICAO-A-COMPRA-DE-TE RRAS-POR-ESTRANGEIROS-E-PRIORIDADE-DE-COMISSAO.html>. Acessed: 14 mar. 2018.

Constitution Bolivia (2009) Constitución Política del Estado, 7/2.

BRAZIL Lei 5.709 (1971) Presidência da República Casa Civil. Subchefia para Assuntos Jurídicos, Brazil.

Ley 26.737. Régimen de Protección al Dominio Nacional sobre la Propiedad, Posesión o Tenencia de las Tierras Rurales. 22. dec. 2011. Republica Argentina.

Ley 1715. Servicio Nacional de Reforma Agraria. Congresso Nacional de Bolívia, 18/10/1996.

Ley 3545.Reconducción de la Reforma Agraria. Congresso Nacional de Bolivia. 28/11/2006.

Ley 477. Ley contra el avasallamiento y tráfico de tierras. La Assemblea Legislativa Plurinacional. Bolivia. 30/12/2013.

\section{Glossary of Acronyms}

ABIN - Brazilian Intelligence Agency

ABIOVE - Brazilian Vegetable Oil Industry Association

AGU - Attorney General of the Union

APROSOJA - Brazilian Association of Soy Producers

CAI - Indigenous Advisory Council

CCIB - Confederation of Intercultural Communities of Bolivia

CNA - National Confederation of Agriculture

CONTAG - National Confederation of Agricultural Workers

CSUTCB - Confederation of Rural Workers of Bolivia 


\section{FAA - Argentinean Agrarian Federation}

INCRA - National Institute for Colonization and Agrarian Reform

NACs - New Agricultural Countries

NGO - Non-Governmental Organization

Repercussões de acordos de compras de terra chineses na América do Sul: vetores de mobilização e instituições domésticas

RESUMO Introdução: O artigo analisa as reações domésticas aos acordos de compras de terras chinesas no Brasil, Argentina e Bolívia e como essas tentativas afetaram a estrutura regulatória desses países para aquisições de terras estrangeiras. Materiais e métodos: As mobilizações contra esses acordos são examinadas com foco em sua composição interna de forças sociais e nas estruturas que elas produzem para pressionar por restrições regulatórias. Resultados: O surgimento de protestos na Argentina e no Brasil, relativo à falta de oposição na Bolívia, é explicado através de um desenho de caso mais semelhante, enfatizando as diferenças na estrutura socioeconômica rural e composição de capital no setor agrícola como fatores explicativos centrais, respondendo pela variação do resultado nos casos examinados. Discussão: Com ponto de partida no debate sobre o investimento global em terras, o artigo contribui para entender como o investimento estrangeiro é acomodado em diferentes modos de desenvolvimento dependente de commodities.

PALAVRAS-CHAVE: Governança da terra; América do Sul; Conflitos pela terra; China; Agronegócio.

This is an Open Access article distributed under the terms of the Creative Commons Attribution Non-Commercial License which permits unrestricted non-commercial use, distribution, and reproduction in any medium provided the original work is properly cited.

A produção desse manuscrito foi viabilizada através do patrocínio fornecido pelo Centro Universitário Internacional Uninter à Revista de Sociologia e Política. 